\title{
USPJEH PODUZEĆA U HIPERKONKURENCIJI: JE LI AGRESIVNO KONKURENTSKO PONAŠANJE DOVOLJNO?
}

\author{
RECONSIDERING SUCCESS IN HYPERCOMPETITION: \\ IS THE AGGRESSIVE COMPETITIVE BEHAVIOR \\ ALL THAT MATTERS?
}

\begin{abstract}
SAŽETAK: Jačanje intenzivnosti interakcije među poduzećima osnovna je značajka novog doba tržišnog natjecanja, u kojemu je sve manje vremena za razvoj ideja kao i za donošenje odluka. Takvi uvjeti se javljaju u industrijama gdje su potezi i akcije poduzeća brzi i česti, kao i reakcije konkurenata, te kada česte interne i eksterne sposobnosti poduzeća eliminiraju poremećaje i diskontinuitet te time sprječavaju održivost konkurentske prednosti. U borbi s konkurentskom realnošću - hiperkonkurencijom, poduzeća moraju biti aktivna u poduzimanju što većeg broja akcija i to što većom brzinom. Agresivnost u poduzimanju akcija smatra se odgovorom poduzeća na fenomen privremene konkurentske prednosti. Poduzeća koja brzo reagiraju na zahtjeve tržišta jačaju svoju tržišnu snagu i stvaraju prednosti, a ona poduzeća koja mogu biti čak i brža, generirat će još veću tržišnu prednost nad svojim konkurentima. Stoga se kao najvažnija značajka konkurentske prednosti u hiperkonkurenciji smatra upravo agresivnost poduzeća u poduzimanju akcija koja se naziva agilnost u kojoj je naglasak na spremnosti na poduzimanje akcija, mjereno razinom do koje je poduzeće spremno participirati u tržišnom natjecanju s konkurentima i brzo djelovati. Stoga je svrha ovoga istraživanja ispitati teorijsku i empirijsku pozadinu ponašanja poduzeća u hiperkonkurentskim uvjetima, kao i načine kako ostati konkurentan u takvim uvjetima. Štoviše, glavni cilj je istražiti postojanje i jačinu utjecaja razine agilnosti poduzeća u poduzimanju akcija na povećanje poslovne uspješnosti poduzeća $u$ hiperkonkurentskim industrijama $u$ Hrvatskoj.
\end{abstract}

KLJUČNE RIJEČI: konkurentska agresivnost, hiperkonkurencija, konkurentsko ponašanje, agilnost poduzeća, tim vrhovnog menadžmenta - TMT. 


\begin{abstract}
A large increase in competition among firms characterizes the new era of competition, resulting in a short time of idea development and even shorter time to make decisions. Such conditions occur when moves and actions of firms are fast and frequent, as well as the competitors' reaction, or when frequent internal and external capabilities destroy disturbances and discontinuities and thus preventing the sustainability of competitive advantage. When dealing with the competitive reality - hypercompetition, firms need to be aggressive by taking a large number of actions with great speed. Action aggressiveness is considered as a firm response to the phenomenon of temporary advantage. Firms able to respond quickly to market demands strengthen their market power and generate advantages; but those that can be even faster, will generate even greater market power and advantage over its competitors. Thus, the most important characteristic of competitive advantage in hypercompetition is aggressiveness in taking actions that is called the firm agility where the focus is on being prepared to take an action, i.e. the extent to which the firm is willing to participate with competitors and act quickly in the involvement and participation. The purpose of this research is to examine the theoretical and empirical background and insights the firms behaviour as well as the ways how to sustain competitive in the context of hypercompetition. Moreover, the main goal is to explore the relation between firm level of agility in taking actions and increase in firm performance in hypercompetitive environments in Croatia.
\end{abstract}

KEY WORDS: competitive aggressiveness, hypercompetition, competitive behavior, firm agility, TMT (Top Management Team).

\title{
1. PONAŠANJE PODUZEĆA U HIPERKONKURENCIJI
}

Strateško ponašanje u hiperkonkurentskoj industriji zahtijeva aktivnu prisutnost na tržištu, odnosno agresivnost poduzeća u poduzimanju akcija. Takvo ponašanje poduzeća je potrebno, no nije i dovoljno. Neke akcije mogu dovesti do ostvarivanja privremene prednosti, dok druge ne moraju uspjeti u tomu (Daraboš Longin, 2016.). Poduzeće će ostvariti dulji period veće uspješnosti ako ima mogućnosti ostvariti prednosti kroz slijed strateških akcija (MacMillan, 1988.) no mora imati u vidu kako poboljšana uspješnost nije rezultat ostvarivanja održive prednosti, već upravo tog niza privremenih prednosti. Brojne studije pokazuju da poduzeća koja godišnje poduzimaju veći ukupan broj akcija od konkurenata, ostvaruju veću dobit (Young, Smith i Grimm, 1996; Daraboš, 2014.a, 2015.), ali i veći tržišni udio (Ferrier, Smith i Grimm, 1999.).

Najznačajniji činitelji koji utječu na strateško ponašanje poduzeća uključuju prepoznavanje konteksta, motivaciju za poduzimanje akcija i sposobnost poduzeća za poduzimanje akcija (Chen, 1996.). Sposobnosti poduzeća trebale bi obuhvaćati organizacijske pretpostavke za jačanje konkurentskog potencijala poduzeća (Ferrier, 2001.), kao i individualne pretpostavke donositelja strateških odluka u poduzeću (Bazerman i Schoorman, 1983.; Daraboš, 2014.a, 2014.b). Ferrier (2001.) pokazuje da što je brži proces donošenja odluke o provođenju akcije, to će povećanje tržišnog udjela poduzeća biti izraženije. Međutim, učestalo poduzimanje akcija podrazumijeva jednostavnije i predvidive akcije što konkurentima omogućuje brži odgovor. Ako izazivači u industriji intenzivnije poduzimaju različite vrste akcija, njihovo ponašanje je nepredvidivo što može zbuniti konkurente i odgoditi njihov odgovor. 
Aktivni konkurentski angažman poduzeća definira se kroz poduzimanje brojnih konkurentskih akcija od strane poduzeća, koje su najčešće ometane odgovorima jednog ili više konkurenata (Ferrier, 2001.). Samo poduzimanje strateške akcije gleda se kao eksterno usmjeren, specifičan i vidljivi konkurentski potez iniciran od strane poduzeća u svrhu poboljšanja konkurentske pozicije (Ferrier, Smith i Grimm, 1999.; Smith i sur., 1991.; Young, Smith i Grimm, 1996.).

Dosadašnja su empirijska istraživanja najčešce pokušala dati odgovore na pitanja o novonastalim uvjetima koje donosi pojava hiperkonkurencije te sve težem održavanju konkurentske prednosti poduzeća pred konkurentima. No, vrlo se malo istraživanja bavilo načinom na koji bi poduzeće trebalo odlučivati, reagirati i napredovati u takvoj okolini. Thomas i D’Aveni (2009.), u longitudinalnom istraživanju o smanjivanju poslovne uspješnosti poduzeća u uvjetima hiperkonkurencije u američkoj prerađivačkoj industriji pokazuju kako bi poduzeća trebala pokušati održati konkurentsku prednost kroz pronalaženje i nadovezivanje niza privremenih prednosti što pretpostavlja poduzimanje većeg broja strateških akcija u određenom vremenskom periodu te na taj način osigurati rast poslovne uspješnosti. Druga istraživanja se pak fokusiraju na utjecaj određenih karakteristika strateških akcija koje poduzeće poduzima na poslovnu uspješnost poduzeća (Ferrier, 2001.) te utjecaj heterogenosti tima vrhovnog menadžmenta (engl. Top Management Team - TMT) na spremnost na poduzimanje akcija (Ferrier, 1999.). Spremnost menadžera na poduzimanje akcija očituje se, između ostalog, kroz poduzetnost članova vrhovnog menadžmenta u formuliranju strategije poduzeća. Poduzetničko ponašanje vrhovnog menadžmenta povezuje se s inovacijom u različitim segmentima poslovanja poduzeća koja omogućuje efikasnu prilagodbu na promjene u okruženju u kojemu poduzeće egzistira (Daraboš, Prester i Tipurić, 2015.).

Tim vrhovnog menadžmenta odlučuje o pravcima razvoja poduzeća, identificira poslovne mogućnosti te koordinira aktivnosti i mobilizira resurse poduzeća kako bi se iskoristile takve mogućnosti što rezultira spremnošću na agresivni konkurentski angažman. U modelu su obilježja tima klasificirana u četiri skupine: kompetencije članova, poduzetnost vrhovnih menadžera, kohezivnost članova i iskustvo vrhovnih menadžera. Obilježja su grupirana u dvije skupine kako bi se ispitao utjecaj definiranih obilježja na stratešku inovativnost odnosno agilnost poduzeća.

Rezultati istraživanja pokazuju kako je stručnost članova vrhovnog menadžmenta važna determinanta strateške inovativnosti poduzeća (Daraboš, 2014.a). Poduzeća čiji članovi vrhovnog menadžmenta imaju više funkcionalnih znanja kao i više znanja o procesima i specifičnostima poduzeća te znanja o djelatnosti u kojoj poduzeće posluje, imaju i značajno višu razinu strateške inovativnosti (Daraboš, 2014.b). Isto tako, poduzetnost vrhovnog menadžmenta pozitivno utječe na stratešku inovativnost poduzeća.

Obavljanje menadžerskih zadaća zahtijeva značajnu razinu komunikacije i interakcije među članovima vrhovnog menadžmenta. Analiza međuodnosa između razine agilnosti i mjere koja opisuje interakciju odnosno kohezivnost među članovima pokazuje pozitivnu vezu (Daraboš, Prester, Tipurić, 2015.). Od iznimne je važnosti da vrhovni menadžment djeluje kao tim i da se na taj način konstantno potiče što veća participacija članova.

Brojna su istraživanja vezana uz analizu postizanja ili zadržavanja iznadprosječne poslovne uspješnosti poduzeća u hiperkonkurentskim industrijama (Chen i MacMillan, 1992.; Chen i Miller, 1994.; Grimm, Lee i Smith, 2006.; Ferrier, Smith i Grimm, 1999.; Chen, Lin i Michel, 2010.; Chen i sur., 2010.; Daraboš Longin, 2016.). 


\section{ANALIZA ODREDNICA KONKURENTSKE AGRESIVNOSTI PODUZEĆA}

Kod traganja za endogenim antecedentima privremene konkurentske prednosti mogao bi se identificirati raspon odnosno opseg do kojega poduzeće svoje odluke, konkurentske akcije i ponašanje podređuje svojim prednostima i čime je takvo ponašanje motivirano. Dok bi se u identificiranju egzogenih antecedenata privremene konkurentske prednosti svakako trebalo sagledati strukturu industrije i industrijske granice odnosno način na koji konvergencija odnosno približavanje industrija i konkurentski poslovni modeli tih industrija potpomažu eroziji prednosti, točnije kako i zašto različite industrijske strukture pridonose brzini erozije (D’Aveni, Dagnino i Smith, 2010.).

Istovjetni institucionalni i makroekonomski uvjeti imaju različite efekte na održivost prednosti što ovisi o industriji koju promatramo, što znači da održiva konkurentska prednost nije jednako ostvariva u svim industrijama.

Chen i sur. (2010.) definiraju intenzivnost hiperkonkurentske okoline kroz stupanj promjenjivosti u osnovnim područjima kroz zahtjeve potrošača i metode proizvodnje u industriji u kojoj poduzeće posluje. Uz različite uvjete koji postoje u pojedinoj hiperkonkurentskoj industriji, poput stupnja agresivnosti konkurenata, njihove sposobnosti u predviđanju akcija, brzine tehnoloških promjena kao i same važnosti tehnoloških karakteristika, pretpostavlja se da poduzeća slijede različite strateške obrasce kako bi zadržali ili postigli konkurentsku prednost (Daraboš, 2014.a, 2015.).

Pretpostavka je da velika poduzeća imaju veći utjecaj na svoju okolinu te se na neki način mogu zaštititi od konkurencije. Iz čega proizlazi da su velika poduzeća sklonija poduzimati učinkovitije i pravovremene konkurentske akcije. Manja poduzeća, s druge strane, su okretnija, fleksibilnija i neprimjetnija te stoga mogu brzo i potajno poduzimati konkurentske akcije (Chen i Hambrick, 1995.).

Nadalje, istraživanja su pokazala konzistentne rezultate koji se odnose na utjecaj veličine poduzeća na konkurentske akcije. Tako su na primjer, Chen i Hambrick (1995.) utvrdili da su mala poduzeća spremnija i odlučnija u poduzimanju akcija u odnosu na velika (sklonost u poduzimanju akcija) i to znatno većom brzinom provedbe akcije. Druge studije pak pokazuju veću vjerojatnost poduzimanja većeg ukupnog broja akcija u određenom vremenskom razdoblju za velika poduzeća (Young, Smith i Grimm, 1994.) kao i poduzimanja akcija koje su više strateške prirode i uočljivije (Chen i Hambrick, 1995.). Nadalje, Miller i Chen (1996.) pokazuju da su velika poduzeća manje sklona konkurentskoj inerciji - zamišljena kao broj tržišno orijentiranih promjena koje poduzeće poduzima u svrhu nadmudrivanja suparnika na tržištu; dok su u svom drugom istraživanju utvrdili da će velika poduzeća vjerojatnije imati jednostavan konkurentski raspored - zamišljen kao set konkurentskih akcija poduzeća koji se sastoji od samo nekoliko različitih vrsta akcija.

Istraživanja su također iznijela dosljedne rezultate s obzirom na ključne odrednice konkurentskog odgovora. Na primjer, veća je vjerojatnost da će velika poduzeća odgovoriti na izazove konkurenata (vjerojatnost odgovora) nego kod malih poduzeća (Chen i Hambrick, 1995.). Međutim, pokazalo se da su odgovori velikih poduzeća ipak suptilniji i manje vidljivi. Također, s obzirom na utjecaj veličine poduzeća na brzinu konkurentskog odgovora, veća poduzeća će brže smisliti i najaviti odgovore na akcije njihovih konkurenata u odnosu na mala poduzeća (Hambrick, Cho i Chen, 1996.). Međutim, velika su poduzeća 
sporija od manjih u smislu vremena koje je proteklo između objave njihovog odgovora i stvarne provedbe odgovora, koji nazivamo brzinom izvršenja (Chen i Hambrick, 1995.).

Smith i suradnici (1991.) su pokazali da što je veća strukturna složenost poduzeća, manja je vjerojatnost da ono reagira na konkurentske izazove. Nadalje, otkrili su da poduzeća koja su strukturno složena odgovaraju nakon drugih poduzeća. Nažalost, ni u ovome se istraživanju nije pokazala nikakva povezanost između strukturne složenosti i brzine odaziva ili imitacije odgovora.

Nadalje, pokazalo se da starija poduzeća često ponavljaju strategije i akcije koje su se u prošlosti pokazale uspješnima (Lant, Millken, i Batra, 1992.; Miller i Chen, 1995.). Stoga, starija poduzeća postaju manje svjesna konkurentskog okruženja i predvidljivija u poduzimanju akcija. Dok, s druge strane, mlađa poduzeća će vjerojatnije izbjegavati konkurentsku jednostavnost te će poduzimati kompleksnije strateške akcije (Miller i Chen, 1996.). Također, kontinuirano će se boriti za pronalaženje resursa što ih motivira da kontinuirano skeniraju okolinu i prate konkurentske prijetnje i prilike koje bi mogle nastati. Starost poduzeća se u dosadašnjim istraživanjima mjerila jednostavno kao vrijeme od osnutka poduzeća do vremena u kojemu je poduzeta strateška akcija poduzeća. Tako su Young i sur. (1996.) pokazali da starija poduzeća poduzimaju manji ukupni broj akcija nego mlađa te da akcije koje poduzimaju odgovaraju normama industrije.

Jedan od najvažnijih indikatora ponašanja poduzeća u budućnosti jest pregled dosadašnjeg ponašanja. Kada su prethodne akcije nekog poduzeća konzistentne i predvidljive, ostala poduzeća pripisuju tom poduzeću određene tendencije ili reputacijske karakteristike (Daraboš, 2015.). Stoga, možemo reći da reputacija odražava informacije povezane s kredibilitetom odnosno vjerodostojnosti poduzeća kao konkurenta. Tako na primjer, poduzeće koje učestalo smanjuje cijene u svrhu zadržavanja ili povećanja tržišnog udjela predstavlja tzv. predatora na tržištu (Smith, Grimm i Gannon, 1992.). Reputacija je u istraživanjima konkurentske dinamike definirana kao pozitivno ili negativno obilježje pripisano nekom konkurentu od strane drugog, a temeljeno na prethodnom konkurentskom ponašanju (Williamson, 1985.; Smith, Grimm i Gannon, 1992.).

Reputacija poduzeća nadalje, mjerena je brojem konkurentskih akcija koje je poduzeće iznijelo u prethodnoj godini. Konkretnije, u svome istraživanju Smith i sur. (1992.) broj poduzetih strateških akcija u prethodnoj godini predstavili su kroz reputaciju poduzeća kao strateškog sudionika, dok su broj akcija koje se odnose na cijenu predstavili kao sklonost poduzeća da postane predator u cijenama. Također, u navedenoj se studiji pokazalo kako su poduzeća s reputacijom strateških sudionika izazvala sporije odgovore konkurenata na poduzete akcije kao i manju vjerojatnost imitacije akcija od strane konkurenata. Dok su, s druge strane, poduzeća s reputacijom cjenovnih predatora izazivali brže odgovore konkurenata na poduzete akcije, no suprotno očekivanjima, njihove su akcije rijetko bile imitirane. Rezultati su pokazali da ne postoji veza između dosadašnje odnosno prethodne reputacije poduzeća i frekvencije odnosno broja odgovora na akcije poduzeća (Daraboš, 2014.a).

Također, drugo je istraživanje pokazalo da će poduzeća s reputacijom tržišnog lidera vjerojatnije privući odgovore i veća je vjerojatnost da će konkurenti njihove akcije imitirati (Smith, Grimm i Gannon, 1992.). Međutim, nije dokazana statistički značajna veza da će akcije tržišnih lidera više privlačiti konkurente na odgovor. Reputacija tržišnog lidera mjerila se tržišnim udjelom poduzeća u prethodnoj godini. Činjenica je da je u uvjetima hiper- 
konkurencije vrlo teško zadržati vodeću poziciju na duži rok te se iz tog razloga istražilo postoji li povezanost između trenutne pozicije poduzeća u industriji sa strateškim ponašanjem odnosno obrascem ponašanja koji poduzeće slijedi (Daraboš, 2014.a). Pokazano je da veza postoji, no nije se pokazala statistički značajnom.

\section{UTJECAJ KONKURENTSKE DINAMIKE NA POSLOVNU USPJEŠNOST PODUZEĆA}

Razna su istraživanja pokušala pronaći vezu između određene vrste akcije i njenog utjecaja na uspješnost poduzeća (Smith, Grimm i Gannon, 1992.; Ferrier, 1997.). Tako se $\mathrm{u}$ istraživanju na uzorku poduzeća u visokotehnološkim industrijama pokazalo da akcije predstavljanja novoga proizvoda dovode do znatnijega povećanja u uspješnosti za razliku od cjenovnih i oglašavačkih akcija, dok, s druge strane, klasifikacija akcija kao strateških u usporedbi s taktičkim nije pokazala promjene u uspješnosti poduzeća (Ferrier, 1997.).

Kod promatranja pojedinačnih odgovora konkurenata pokazalo se da su poduzeća čije su akcije izazvale ukupno manje odgovora postigla bolju uspješnost (Chen i Miller, 1994.). Nekoliko je istraživanja proučavalo i utjecaj brzine odgovora kao jedne od varijable na uspješnost poduzeća. Smith i sur. (1991., 1992., 1997.) su na uzorku poduzeća u industriji zrakoplovnog prijevoza pokazali negativnu povezanost između navedenih varijabli. Također, pokazalo se da ukoliko manja poduzeća iskaču od industrijskih normi u brzini odgovora postižu slabiju uspješnost (Chen i Hambrick, 1995.). S druge strane, kada se u promatranje uzme i varijabla redoslijed odgovora (redoslijed kojim su konkurenti odgovarali na pojedinu akciju), pokazalo se da je brzina odgovora pozitivno povezana s uspješnošću poduzeća kroz mnoge proučavane industrije (Lee i sur., 2000.; Smith i sur., 1991.; Smith, Grimm i Gannon, 1992.). Navedeno ukazuje na činjenicu da i drugi čimbenici utječu na vezu između brzine odgovora i uspješnosti, dok naravno, redoslijed odgovora sam po sebi ima važnu ulogu.

U većini dosadašnjih istraživanja gledao se odnos između poduzimanja akcije od strane poduzeća i odgovora konkurenata na tu akciju (Chen, Smith i Grimm, 1992.). Rezultati pokazuju da su karakteristike i očekivana korist od strateške akcije vrlo važni pokazatelji odnosno prediktori odgovora konkurenata (Grimm i Smith, 1997.). Također, istražena je veza između poduzimanja akcija i poslovne uspješnosti poduzeća kroz skupno gledanje na karakteristike i učestalost specifičnih akcija i odgovora u određenom vremenskom periodu - kroz godinu dana (Chen, Smith i Grimm, 1999.; Smith, Grimm i Gannon, 1992.; Young, Smith i Grimm, 1996.) ili kroz mjesec dana (Makadok, 1998.). Pokazuje se da što je veći konkurentski angažman poduzeća odnosno što više akcija poduzima poduzeće u određenom periodu i što većom brzinom, to je vjerojatnije da će se poslovnu uspješnost poduzeća poboljšati i povećati tržišni udio poduzeća.

Neki su istraživači analizirali strategiju kao cjelokupni repertoar konkurentskih akcija poduzeća u određenoj godini te došli do zaključka da širi i složeniji repertoar akcija koje poduzeće poduzima dovodi do bolje poslovne uspješnosti i tržišnog udjela poduzeća (Ferrier, Smith i Grimm, 1999.; Miller i Chen, 1994.; Miller i Chen, 1996.). Također, istraživao se i utjecaj vrste i trenutka poduzimanja akcija na poslovnu uspješnost poduzeća (Lee i sur., 2000.). 
Istraživanja u području strateškog menadžmenta tradicionalno su promatrala elemente financijske uspješnosti (poput profitabilnosti, rasta prodaje, cijene dionica i sl.) kao zavisne ili ishodne varijable poslovne uspješnosti poduzeća. No, vrlo je važno na koji način financijska uspješnost utječe na buduće akcije poduzeća (Thompson, 1967.). Istraživanja su pokazala da će uspješnija poduzeća rjeđe odgovarati na izazove konkurenata (Hambrick, Cho i Chen, 1996.), a ako i odgovore, ti su odgovori znatno sporiji. Također, poduzeća s višom poslovnom uspješnošću češće će poduzimati jednostavan (suprotno od kompleksnog) slijed strateških akcija tijekom vremena (Daraboš Longin, 2016.).

Ipak, suprotno predviđenom, dobra prethodna uspješnost poduzeća pozitivno je povezana s ukupnim brojem konkurentskih akcija koje poduzeće poduzima (Young, Smith i Grimm, 1996.). To se može dogoditi iz razloga što su vrlo uspješna, dominantna poduzeća svjesna da ukoliko žele zadržati poziciju na tržištu moraju poduzimati agresivne konkurentske akcije poput postavljanja predatornih cijena, širenja ponude proizvoda, oglašavanja te povećanja kapaciteta (Scherer i Ross, 1990.). S druge strane, isto se ponašaju i poduzeća s lošijom poslovnom uspješnosti, u cilju poboljšanja svoje konkurentske pozicije (MacFhionnlaoich i sur., 1996.).

Poduzeća surađuju međusobno kroz poduzimanje akcija i odgovora u svrhu postizanja određenih konkurentskih rezultata. Poslovna uspješnost poduzeća može se mjeriti različitim pokazateljima uspješnosti, međutim najčešće se koriste financijski pokazatelji uspješnosti, računovodstveni i tržišni. U većini svjetskih istraživanja ovoga tipa, kao mjere uspješnosti poduzeća istraživači koriste tržišne pokazatelje uspješnosti. Rezultati su se očitovali kroz mjere uspješnosti poduzeća poput promjena u tržišnome udjelu (Chen i MacMillan, 1992.; Ferrier, Smith i Grimm, 1999.), kumulativnih iznadprosječnih povrata dioničarima (Lee i sur., 2000.), rasta prodaje (Ferrier, 2000.) te kroz računovodstvene mjere profitabilnosti i rasta dobiti, kao što je povrat na ulaganja (ROI) i sl. (Hambrick, Cho i Chen, 1996.; Smith i sur., 1991.; Young, Smith i Grimm, 1996.). Najčešće mjere koje se koriste za iskazivanje promjena u uspješnosti poduzeća ovise i o posebnostima industrije u kojoj poduzeće posluje.

Poslovna uspješnost poduzeća može se promatrati i kroz promjene u tržišnome udjelu. Povećanje ili zadržavanje tržišnoga udjela vrlo je važan cilj mnogih poduzeća jer na taj način poduzeća mogu zadržati poziciju lidera u industriji, zamijeniti lidera ili smanjiti razliku u tržišnome udjelu u odnosu na vodeća poduzeća. Visoki tržišni udio obično vodi povećanju prihoda poduzeća koje proizlazi iz ekonomije razmjera, tržišne snage i prednosti proizašle iz reputacije (Anderson i Zeithaml, 1984.; Buzzell, Gale i Sultan 1975.; Porter, 1980.). Štoviše, tržišni udio također predstavlja mjeru relativne pozicije u odnosu na konkurente i, što je još važnije, menadžeri vjeruju da je povezan s povećanjem prihoda (Armstrong i Collopy, 1996.; Song, Di Benedetto i Zhao, 1999.). Prema tome, promjene u tržišnome udjelu predstavljaju važan organizacijski ishod za poduzeća, budući da se odnosi i na pozitivne (rast) i negativne (pad) relativne pomake u odnosu na konkurente, kao i na profitni potencijal (Daraboš Longin, 2016.). 


\section{METODOLOGIJA I REZULTATI EMPIRIJSKOGA ISTRAŽIVANJA}

Empirijski dio ovoga istraživanja odnosi se na kvantitativno istraživanje utjecaja razine agilnosti poduzeća na poslovnu uspješnost poduzeća u hiperkonkurentskim industrijama u Republici Hrvatskoj. Drugim riječima, cilj ovoga istraživanja je utvrditi postoji li statistički značajna razlika u uspješnosti poduzeća s obzirom na njihovu sposobnost i učestalost $u$ poduzimanju akcija.

Osnovni skup za ovo empirijsko istraživanje čine poduzeća koja posluju u industriji mobilne telekomunikacije (prema Nacionalnoj klasifikaciji djelatnosti (NKD) uključuje: J 61.20 Djelatnosti bežične telekomunikacije), kozmetičkoj industriji (G 46.45 Trgovina na veliko parfemima i kozmetikom te C 20.41 Proizvodnja sapuna i deterdženata, sredstava za čišćenje i poliranje, parfema i toaletno kozmetičkih preparata), tiskarskoj industriji (C 18.1 Tiskanje i uslužne djelatnosti povezane s tiskanjem) i industriji maloprodajnih lanaca (G 47.11 Trgovina na malo u nespecijaliziranim prodavaonicama pretežno hranom, pićima i duhanskim proizvodima). Važno je napomenuti da su se jasno odredile granice svake pojedine industrije kako bi u osnovni skup uključili samo ona poduzeća iz četiriju industrija koja posluju u hiperkonkurentskim uvjetima.

S obzirom da je jedinica promatranja u ovome empirijskom istraživanju poduzeće, stopa povrata iznosi $58,65 \%$ što je, u odnosu na prosječni povrat u istraživanjima ovoga tipa i ekstenzivnost samog anketnog upitnika, iznimno dobar povrat.

Ključan konstrukt i doprinos ovoga istraživanja predstavlja utvrđivanje konstrukta agilnosti poduzeća. Agilnost poduzeća definirana je dvjema varijablama koje podrobnije objašnjavaju i prikazuju poduzimanje strateških akcija od strane poduzeća. Prva je varijabla učestalost poduzimanja određenih kategorija odnosno vrsta strateških akcija. Navedena varijabla mjeri poduzimanje određenih vrsta akcija od strane poduzeća u odnosu na izravne konkurente. Druga varijabla jest brzina reakcije poduzeća koja pokazuje prepoznavanje, reagiranje i predviđanje strateških prilika i izazova u okolini od strane poduzeća u usporedbi s brzinom izravnih konkurenata. Pretpostavka je da što je veća agilnost poduzeća odnosno viša učestalost poduzimanja akcija, to je veća vjerojatnost da će poduzeće uspjeti u ostvarivanju privremene konkurentske prednosti.

Najprije je istraženo postoji li razlika u poslovnoj uspješnosti s obzirom na razinu agilnosti poduzeća. Za potrebe testiranja navedene teze provedena je regresijska analiza međuovisnosti navedenih varijabli. Varijabla „,razina agilnosti“ $u$ analizi predstavlja nezavisnu varijablu, a korištena je kao srednja vrijednost dvije varijable koje ju opisuju (učestalost u poduzimanju akcija i brzina reakcije poduzeća) te poprima vrijednosti od minimalno 1 do maksimalno 5. Iz tablice 1. vidljivo je kako prosječna razina agilnosti poduzeća iz uzorka iznosi 3,26, drugim riječima, rezultati pokazuju kako hrvatska poduzeća iz uzorka imaju visoku razinu agilnosti što znači da poduzimaju veliki broj akcija te brzo reagiraju na nastale promjene u okolini.

U modelu smo razinu agilnosti jednaku ili veću od 3,00 definirali kao visoku razinu određene varijable, a srednje vrijednosti ispod 3,00 predstavljaju nisku razinu određene varijable. Iz korištene skale vidi se kako vrijednosti jednake 3,00 ili iznad pokazuju značajnu aktivnost na tržištu u usporedbi s izravnim konkurentima, za razliku od vrijednosti ispod 3,00 koje pokazuju manju aktivnost na tržištu u usporedbi s najvažnijim konkurentima. 
Tablica 1. Razina agilnosti poduzeća iz uzorka

\begin{tabular}{|c|c|c|c|c|}
\hline & $\mathbf{N}$ & $\begin{array}{c}\text { Minimalna } \\
\text { vrijednost }\end{array}$ & $\begin{array}{c}\text { Maksimalna } \\
\text { vrijednost }\end{array}$ & $\begin{array}{c}\text { Srednja } \\
\text { vrijednost }\end{array}$ \\
\hline A11 broj poduzetih cjenovnih akcija & 61 & 1 & 5 & 3,38 \\
\hline A12 broj poduzetih marketinških akcija & 61 & 1 & 5 & 3,15 \\
\hline $\begin{array}{l}\text { A13 broj poduzetih akcija predstavljanja } \\
\text { proizvoda }\end{array}$ & 61 & 1 & 5 & 3,18 \\
\hline $\begin{array}{l}\text { A14 broj poduzetih akcija vezanih uz } \\
\text { kapacitet i razmjer }\end{array}$ & 61 & 1 & 5 & 2,98 \\
\hline $\begin{array}{l}\text { A15 broj poduzetih uslužnih i } \\
\text { operacijskih akcija }\end{array}$ & 61 & 1 & 5 & 3,15 \\
\hline $\begin{array}{l}\text { A16 broj poduzetih javnih akcija } \\
\text { signaliziranja }\end{array}$ & 61 & 1 & 5 & 2,85 \\
\hline $\begin{array}{l}\text { A1) Učestalost poduzimanja } \\
\text { određenih vrsta strateških akcija } \\
\text { (A11 - A16) }\end{array}$ & 61 & $\mathbf{1 , 5 0}$ & 5 & 3,12 \\
\hline $\begin{array}{l}\text { A21 prepoznavanje strateških prilika i } \\
\text { izazova u okolini }\end{array}$ & 61 & 1 & 5 & 3,39 \\
\hline $\begin{array}{l}\text { A22 reagiranje poduzeća na strateških } \\
\text { prilike i izazove u okolini }\end{array}$ & 61 & 1 & 5 & 3,36 \\
\hline $\begin{array}{l}\text { A23 iskorištavanje strateških prilika i } \\
\text { izazova u okolini }\end{array}$ & 61 & 1 & 5 & 3,44 \\
\hline $\begin{array}{l}\text { A24 predviđanje strateških prilika i } \\
\text { izazova u okolini }\end{array}$ & 61 & 2 & 5 & 3,44 \\
\hline $\begin{array}{l}\text { A2) Brzina reakcije poduzeća } \\
\text { (A21 - A24) }\end{array}$ & 61 & 1,50 & 5 & 3,41 \\
\hline $\begin{array}{l}\text { AGILNOST PODUZEĆA } \\
(\mathbf{A}=\mathbf{A} 1+\mathbf{A} 2)\end{array}$ & 61 & $\mathbf{1 , 5 0}$ & 4,92 & 3,26 \\
\hline
\end{tabular}

Budući su varijable koje definiraju agilnost poduzeća produkt većeg broja tvrdnji, pouzdanost mjernih ljestvica analizirana je Cronbach alpha koeficijentom, koji iznosi 0,898 te pokazuje kako su kompozitne varijable prilično konzistentne odnosno pokazuju kako se tvrdnje korištene u konstrukciji varijabli vrlo dobro „slažu“.

Nadalje, istražili smo i odnos između kompozitnih varijabli koje konstruiraju varijablu agilnosti poduzeća. Koeficijenti korelacije predstavljeni su u tablici 2. i pokazuju intenzitet povezanosti varijabli od interesa, kao i statističku značajnost utvrđenih korelacija. 
Tablica 2. Korelacija između kompozitnih varijabli konstrukta agilnosti poduzeća

\begin{tabular}{|c|c|c|c|c|c|c|c|c|c|c|}
\hline & A11 & A12 & A13 & A14 & A15 & A16 & A21 & A22 & A23 & A24 \\
\hline A11 broj poduzetih cjenovnih akcija & & $0,398^{* * *}$ & $0,359^{* * *}$ & $0,413^{* * *}$ & $0,315^{* *}$ & $0,576^{* * *}$ & $0,319^{* *}$ & $0,384^{* * *}$ & $0,407^{* * *}$ & $0,240^{*}$ \\
\hline $\begin{array}{l}\text { A12 broj poduzetih marketinških } \\
\text { akcija }\end{array}$ & & & $0,678^{* * *}$ & $0,444^{* * *}$ & $0,552^{* * *}$ & $0,640^{* * *}$ & 0,149 & $0,233^{*}$ & $0,319^{* * *}$ & 0,179 \\
\hline $\begin{array}{l}\text { A13 broj poduzetih akcija } \\
\text { predstavljanja proizvoda }\end{array}$ & & & & $0,441^{* * *}$ & $0,306^{* *}$ & $0,681^{* * *}$ & $0,328^{* *}$ & $0,290^{* *}$ & $0,340^{* * *}$ & $0,284^{* *}$ \\
\hline $\begin{array}{l}\text { A14 broj poduzetih akcija vezanih uz } \\
\text { kapacitet i razmjer }\end{array}$ & & & & & $0,754^{* * *}$ & $0,471^{* * *}$ & $0,456^{* * *}$ & $0,472^{* * *}$ & $0,495^{* * *}$ & $0,368^{* * *}$ \\
\hline $\begin{array}{l}\text { A15 broj poduzetih uslužnih i } \\
\text { operacijskih akcija }\end{array}$ & & & & & & $0,503^{* * *}$ & $0,420^{* * *}$ & $0,457^{* * *}$ & $0,481^{* * *}$ & $0,363^{* * *}$ \\
\hline $\begin{array}{l}\text { A16 broj poduzetih javnih akcija } \\
\text { signaliziranja }\end{array}$ & & & & & & & $0,458^{* * *}$ & $0,513^{* * *}$ & $0,584^{* * *}$ & $0,408^{* * *}$ \\
\hline $\begin{array}{l}\text { A21 prepoznavanje strateških prilika } \\
\text { i izazova u okolini }\end{array}$ & & & & & & & & $0,876^{* * *}$ & $0,777^{* * *}$ & $0,719^{* * *}$ \\
\hline $\begin{array}{l}\text { A22 reagiranje poduzeća na } \\
\text { strateških prilike i izazove u okolini }\end{array}$ & & & & & & & & & $0,851^{* * *}$ & $0,775^{* * *}$ \\
\hline $\begin{array}{l}\text { A23 iskorištavanje strateških prilika i } \\
\text { izazova u okolini }\end{array}$ & & & & & & & & & & $0,723^{* * *}$ \\
\hline $\begin{array}{l}\text { A24 predviđanje strateških prilika i } \\
\text { izazova u okolini }\end{array}$ & & & & & & & & & & \\
\hline
\end{tabular}

*** Razina signifikantnosti je $<0.01 ; \mathrm{N}=61$.

** Razina signifikantnosti je $<0.05 ; \mathrm{N}=61$.

* Razina signifikantnosti je $<0.1$; N=61. 
Rezultati korelacijske analize pokazuju kako između svih parova pomoćnih varijabli od kojih se sastoje varijable agilnost i strateška inovativnost poduzeća postoji povezanost. Najsnažniju vezu $\left(r_{p}=0,876\right.$; sig=.000) zabilježili smo između pomoćnih varijabli koje opisuju brzinu reakcije poduzeća i to između varijabli A21 - prepoznavanje strateških prilika i izazova u okolini i A22 - reagiranje poduzeća na strateške prilike i izazove u okolini.

Slično, izrazito jaka korelacija postoji između varijabli A22 - reagiranje poduzeća na strateške prilike i izazove u okolini i A23 - iskorištavanje strateških prilika i izazova u okolini $\left(r_{p}=0,851\right.$; sig=.000). Najslabiju, ali opet pozitivnu vezu $\left(r_{p}=0,240 ;\right.$ sig=.062) zabilježili smo između varijabli A11 - broj poduzetih akcija i A24 - predviđanje strateških prilika i izazova u okolini uz razinu signifikantnosti manju od $10 \%$, ali i između varijabli A13 i A22 - reagiranje poduzeća na strateške prilike i izazove u okolini $\left(\mathrm{r}_{\mathrm{p}}=0,290\right.$; sig=.024) kao i A24 - predviđanje strateških prilika i izazova u okolini $\left(r_{p}=0,284\right.$; sig=.027) gdje je veza statistički značajna na razini signifikantnosti manjoj od $5 \%$.

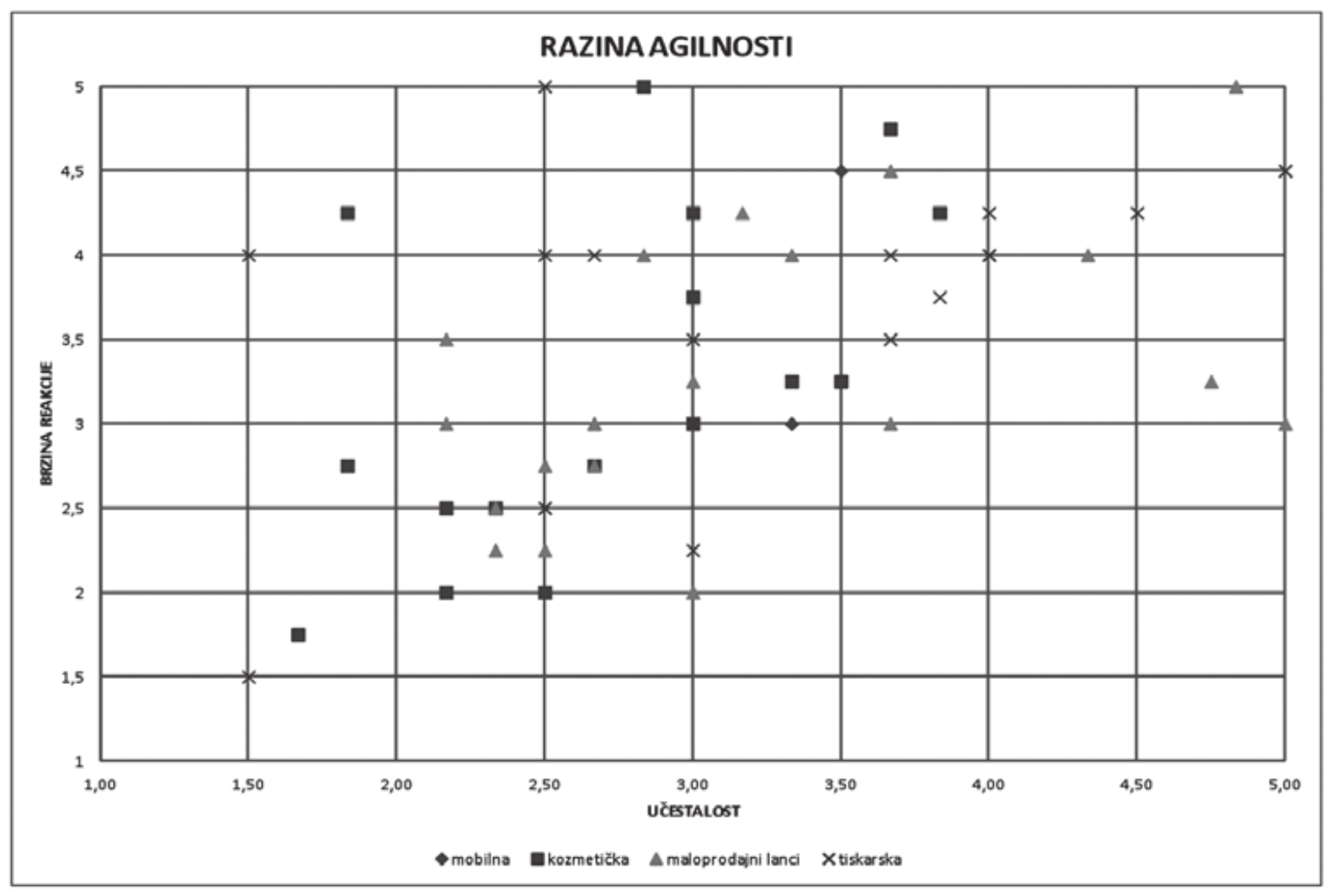

Slika 1. Poduzeća iz uzorka prema razini agilnosti

Visoko agilna su ona poduzeća koja su izrazito natjecateljski orijentirana te svoje poslovanje unapređuju i usavršavaju u svakom pogledu. Poduzeće je u stanju nadvladati suparnike ako je kontinuirano bolje ili ako je predvodnik u industriji pa iskorištava svoje prednosti kako bi još više ojačalo svoj ugled i povećalo tržišni udio.

Za potrebe istraživanja utjecaja razine agilnosti na poslovnu uspješnost poduzeća u hiperkonkurenciji istraženo je postoji li razlika u poslovnoj uspješnosti s obzirom na razinu agilnosti poduzeća. Za potrebe testiranja navedene teze provedena je regresijska analiza međuovisnosti navedenih varijabli. 
U tablici 3. prikazani su i opisani rezultati regresijske analize za mjeru poslovne uspješnosti iskazanu kroz trogodišnji prosjek rasta poslovnih prihoda za koje je pokazana statistički značajna i pozitivna veza s razinom agilnosti.

Tablica 3. Regresijska analiza za utvrđivanje međuovisnosti trogodišnjeg rasta poslovnih prihoda i razine agilnosti poduzeća

\section{Summary of Fit}

\begin{tabular}{|l|r|}
\hline RSquare & 0,044865 \\
\hline RSquare Adj & 0,028677 \\
\hline Root Mean Square Error & 0,268106 \\
\hline Mean of Response & 0,081707 \\
\hline Observations (or Sum Wgts) & 61 \\
\hline
\end{tabular}

\section{Analysis of Variance}

\begin{tabular}{|l|c|c|c|c|}
\hline Source & DF & Sum of Squares & Mean Square & F Ratio \\
\hline Model & 1 & 0,1992101 & 0,199210 & 2,7714 \\
\hline Error & 59 & 4,2409602 & 0,071881 & Prob > F \\
\hline C. Total & 60 & 4,4401703 & & 0,0903 \\
\hline
\end{tabular}

\section{Parameter Estimates}

\begin{tabular}{|l|c|c|c|c|}
\hline Term & Estimate & Std Error & t Ratio & Prob> $|\mathbf{t}|$ \\
\hline Intercept & $-0,163461$ & 0,151218 & $-1,08$ & 0,2841 \\
\hline RAZINA AGILNOSTI & 0,0750919 & 0,045107 & 1,66 & 0,0903 \\
\hline
\end{tabular}

Rezultati pokazuju kako postoji statistički značajna razlika u stopi trogodišnjeg rasta poslovnih prihoda u odnosu na razinu agilnosti poduzeća odnosno pokazuju da je stopa trogodišnjeg rasta poslovnih prihoda poduzeća značajno bolja što je viša razina agilnosti. Utvrđena se razlika pokazuje statistički značajnom na razini signifikantnosti od $10 \%$ (sig=.090), a ovim je modelom objašnjeno 4,49 \% varijance.

Temeljem rezultata provedene regresijske analize međuovisnosti razine agilnosti i pokazatelja poslovne uspješnosti poduzeća, može se donijeti zaključak kako veza između navedenih varijabli postoji te je za objektivne pokazatelje uspješnosti (trogodišnji rast ukupnih i poslovnih prihoda) ona značajna na razini signifikantnosti od $10 \%$.

\section{ZAKLJUČAK}

Konkurentska dinamika sve je izraženija u mnogim industrijama, štoviše i u onima koje su se donedavno smatrale relativno stabilnima. Prisutan je pomak u konkurentskim uvjetima u različitim industrijama koji je vidljiv kroz nagli porast konkurentske aktivnosti, 
veću promjenljivost u profitabilnosti industrija, kao i izraženiju promjenu u tržišnim udjelima. Prednosti poduzeća postaju više privremene naravi budući da su u okolini prisutni razni poremećaji, a potezi i aktivnosti konkurenata sve su učestaliji pa poduzeća moraju konstantno osmišljavati i pronalaziti nove prednosti i stalno pratiti promjene na tržištu i poteze konkurenata.

Iako u svijetu raste broj empirijskih istraživanja koja se bave problematikom postizanja i zadržavanja konkurentske prednosti u hiperkonkurenciji, ona u prvome redu u fokusu imaju analizu konkurentske dinamike i utjecaj na financijsku uspješnost poduzeća. Time je ostavljen veliki istraživački prostor u analiziranju i promatranju utjecaja specifičnih internih obilježja poduzeća na strateško ponašanje poduzeća te povezanost određenog ponašanja odnosno strateškog obrasca koji poduzeće slijedi s postizanjem i zadržavanjem konkurentske prednosti u hiperkonkurentskim industrijama.

Rezultati istraživanja pokazuju da razina agilnosti poduzeća odnosno učestalost poduzimanja strateških akcija od strane poduzeća predstavlja značajan prediktor vjerojatnosti da će poduzeće koje posluje u hiperkonkurentskim uvjetima ostvariti rast profitabilnosti. Pokazalo se kako postoji statistička međuzavisnost između razine agilnosti i nekih objektivnih pokazatelja poslovne uspješnosti, poput trogodišnjeg rasta ukupnih i poslovnih prihoda u hrvatskim poduzećima. Drugim riječima, rezultati istraživanja pokazuju da su poduzeća iz uzorka koja poduzimaju veći broj akcija u nekom periodu i to velikom brzinom te su sposobna brzo prepoznati i reagirati na promjene u okolini ostvaruju višu razinu poslovne uspješnosti. Poduzeća iz uzorka u prosjeku su visoko agilna (razina agilnosti 3,26) i izrazito su natjecateljski orijentirana te svoje poslovanje unapređuju i usavršavaju u svakome pogledu. Svjesna su svoje pozicije i pravila borbe za opstanak i uspjeh u hiperkonkurenciji.

Obzirom da je privremena konkurentska prednost još uvijek nedostatno empirijski istražena, jedno od ograničenja istraživanja predstavlja nemogućnost komparativnog istraŽivanja ili primjerice nadogradnje već rafiniranih instrumenata, kao što je to slučaj s održivom konkurentskom prednosti, stoga bi se moglo reći da je zapravo riječ o pionirskom istraživanju. Nadalje, ograničenja provedenoga istraživanja u najvećemu se dijelu odnose na metodološke aspekte istraživanja. Korištenje anketnog upitnika kao metode prikupljanja podataka i oslanjanje na subjektivna mišljenja ispitanika odnosno korištenje uglavnom perceptivnih mjera povlači sa sobom problem pristranosti, iskrenosti i objektivnosti. U ovome istraživanju koristile su se direktne mjere konstruirane iz odgovora članova vrhovnog menadžmenta te ova ograničenja treba staviti u perspektivu s prednostima ovakvog tipa istraživanja. Zatim, velik broj mjera korištenih u istraživanju (prije svega pokazatelji poslovne uspješnosti) nije prikupljen putem anketnog upitnika već iz različitih sekundarnih izvora podataka te samim time točnost podataka ovisi o ispravnosti tih baza.

Rezultati i zaključci istraživanja provedenoga na poduzećima u Republici Hrvatskoj koja djeluju u hiperkonkurentskim industrijama, pružaju empirijske dokaze koji mogu pomoći u razumijevanju determinanti ponašanja poduzeća u takvim uvjetima. 


\section{LITERATURA:}

1. Anderson, C. R. \& Zeithaml, C. P. (1984). Stage of the Product Life Cycle, Business Strategy, and Business Performance. Academy of Management Journal. 27(1), 5-24.

2. Armstrong, J. S. \& Collopy, F. (1996). Competitor Orientation: Effects of Objectives and Information on Managerial Decisions and Profitability. American Marketing Association. 26(1), 188-199.

3. Bazerman, M. H. \& Schoorman, F. D. (1983). A Limited Rationality Model of Interlocking Directorates. Academy of Management Review. 8(2), 206-217.

4. Buzzell, R., Gale, B. \& Sultan, R. (1975). Market Share - A Key to Profitability. Harvard Business Review. 53(1), 97-106.

5. Chen, M. J. \& Hambrick, D. C. (1995). Speed, Stealth, and Selective Attack: How Small Firms Differ from Large Firms in Competitive Behavior. Academy of Management Journal. 38(2), 453-482.

6. Chen, E. L. et. al. (2010). Life in the Fast Lane: Origins of Competitive Interaction in New versus Established Markets. Strategic Management Journal, 31(13), 1527-1547.

7. Chen, M. J. (1996). Competitor Analysis and Interfirm Rivalry: Toward a Theoretical Integration. Academy of Management Review, 21(1), 100-134.

8. Chen, M. J. \& MacMillan, I. C. (1992). Nonresponse and Delayed Response to Competitive Moves: The Roles of Competitor Dependence and Action Irreversibility. Academy of Management Journal. 35(3), 539-570.

9. Chen, M. J. \& Miller, D. (1994). Competitive Attack, Retaliation and Performance: An Expectancy-valence Framework. Strategic Management Journal. 15(2), 85-102.

10. Chen, M. J., Lin, H. C. \& Michel, J. G. (2010). Navigating in a Hypercompetitive Environment: The Roles of Action Aggressiveness and TMT Integration. Strategic Management Journal. 31(13), 1410-1430.

11. Chen, M. J., Smith, K. G. \& Grimm, C. M. (1992). Action Characteristics as Predictors of Competitive Responses. Management Science. 38(3), 439-455.

12. Daraboš, M. (2014). Strateški obrasci i konkurentska prednost poduzeća u hiperkonkurentskim uvjetima. Doctoral dissertation, Faculty of economics and bussines, Zagreb. (in Croatian)

13. Daraboš, M. (2014). Top Management Team Cohesiveness and Firm Agility. In Tipurić, D., Vrdoljak, R. I. \& Podrug, N. (Eds.), Rethinking Corporate Governance (pp. 154-165). Harlow, England: Pearson Education.

14. Daraboš, M. (2015). Evolucija konkurentske prednosti: U potrazi za uspjehom u hiperkonkurentskim uvjetima. Zagreb: Naklada Ljevak. (in Croatian)

15. Daraboš, M., Prester, J. \& Tipurić, D. (2015). Entrepreneurial Spirit of Top Management Team: Is there any Influence on Strategic Innovation? In Tipurić, D., Vrdoljak, R. I. \& Daraboš, M. (Eds.), Dynamics of organizational change: Beyond identity and reputation (pp. 35-46). Harlow,England: Pearson Education Limited.

16. Daraboš Longin, M. (2016). Firm strategic behaviour in hypercompetition: Is there a link with sustainable competitive advantage? International Journal of Arts and Sciences, 9(2), 667-675. 
17. D'Aveni, R. A., Dagnino, G. B. \& Smith, K. G. (2010). The Age of Temporary Advantage? Strategic Management Journal. 31(13), 1371-1385.

18. Ferrier W. J., Smith, K. G. \& Grimm, C. M. (1999). The Role of Competitive Action in Market Share Erosion and Industry Dethronement: A Study of Industry Leaders and Challengers. Academy of Management Journal. 42(4), 372-388.

19. Ferrier, W. J. (1997) . Tough Talk and Market Leaders: The Role of Overt Signaling and Reputation-Building Behaviors in Sustaining Industry Dominance. Corporate Reputation Review, 1(2), 98-103.

20. Ferrier, W. J. (1999). Win or Lose How You Play The Game Does Matter: The Process and Consequences of Dynamic Competitive Interaction. Berlin, Germany: Paper presented at the Strategic Management Society Annual International Conference.

21. Ferrier, W. J. (2001). Navigating the Competitive Landscape: The Drivers and Consequences of Competitive Aggressiveness. Academy of Management Journal. 44 (4), 858-877.

22. Ferrier, W. J., Mac Fhionnlaoich, C., Smith, K. G., \& Grimm, C. M. (2002). The impact of performance distress on aggressive competitive behavior: A reconciliation of conflicting views. Managerial and Decision Economics. 23, 301-316.

23. Grimm, C. M. \& Smith, K. G. (1997). Strategy as Action: Industry Rivalry and Cordination. Cincinnati: South-Western College Publishing.

24. Grimm, C. M., Lee, H. \& Smith, K. G. (2006). Strategy as Action: Competitive Dynamics and Competitive Advantage. New York: Oxford University Press.

25. Hambrick, D. C., Cho, T. S. \& Chen, M. J. (1996). The Influence of Top Management Team Heterogeneity on Firms' Competitive Moves. Administrative Science Quarterly. 41(4), 659-684.

26. Lant, T. K., Millken, F. J. \& Batra, B. (1992). The Role of Managerial Learning and Interpretation in Strategic Persistence and Reorientation: An Empirical Exploration. Strategic Management Journal. 13(8), 580-608.

27. Lee, C. H. et. al. (2010). Complementarity-Based Hypercompetition in the Software Industry: Theory and Empirical Test, 1990-2002. Strategic Management Journal. 31 (13), 1431-1456.

28. MacMillan, I. C. (1988). Controlling Competitive Dynamics by Taking Strategic Initiative. Academy of Management Executive. 2(2), 111-118.

29. Makadok, R. (1998). Can First-mover and Early-mover Advantages be Sustained in an Industry with Low Entry Barriers to Entry/Imitation? Strategic Management Journal. 19(7), 683-696.

30. Miller, D. \& Chen, M. J. (1995). Nonconformity in Competitive Repertoires. Academy of Management Best Paper Proceedings. 1, 256-261.

31. Miller, D. \& Chen, M. J. (1994). Sources and Consequences of Competitive Inertia: A Study of the U.S. Airline Industry. Administrative Science Quarterly. 39(1), 1-23.

32. Miller, D. \& Chen, M. J. (1996). The Simplicity of Competitive Repertoires. Strategic Management Journal. 17(6), 419-440.

33. Scherer, F. M. \& Ross, D. (1990). Industrial Market Structure and Economic Performance. Boston: Houghton Mifflin. 
34. Smith, K. G. et al. (1991). Organizational Information Processing, Competitive Responses, and Performance in the U.S. Domestic Airline Industry. Academy of Management Journal. 34(1), 60-85.

35. Smith, K. G. et. al. (1997). Strategic Groups and Rivalrous Firm Behavior: Towards a Reconciliation. Strategic Management Journal. 18(2), 149-157.

36. Smith, K. G., Ferrier, W. J. \& Grimm, C. M. (2001). King of the Hill: Dethroning the Industry Leader. The Academy of Management Executive. 15(2), 59-70.

37. Smith, K. G., Grimm, C. M. \& Gannon, M. J. (1992). Dynamics of Competitive Strategy. Newbury Park, CA: Sage Publications.

38. Song, X. M., Di Benedetto, C. A. \& Zhao, Y. L. (1999). Pioneering advantages in manufacturing and service industries: empirical evidence from nine countries. Strategic Management Journal. 20(9), 811-836.

39. Thomas, L. G. \& D'Aveni, R. A. (2009). The Changing Nature of Competition in the U.S. Manufacturing Sector, 1950-2002. Strategic Organization. 7(4), 387-431.

40. Thompson, J. D. (1967). Organization in Action. New York: McGraw-Hill.

41. Williamson, O. E. (1985). The Economic Institutions of Capitalism. New York: Free Press.

42. Young, G., Smith, K. G.\& Grimm, C. M. (1996). "Austrian“" and Industrial Organization Perspectives on Firm-level Competitive Activity and Performance. Organization Science. 7(3), 243-254. 